\title{
Analysis of Issues and Challenges in Developing Secondary School Students' Skills in English Language
}

\author{
Dr. Muhammad Yousuf Sharjeel \\ Associate Professor \\ Faculty of Social Sciences \& Humanities \\ Hamdard University \\ yousufsharjeel@hotmail.com \\ Erum Khan \\ M.Phil Research Fellow \\ Hamdard University \\ Abdul Nasir Kiazai
Director, Institute of Education \& Research,
University of Balochistan \\ Dr. Zarina Waheed \\ Lecturer, Department of Education SBK Women's University
}

\begin{abstract}
Several Pakistani secondary school students from various popular institutes undergo a variety of problems and difficulties due to their inability to demonstrate a genuine and natural skill to use English language in real life. The situation under which English at the secondary level is taught in Pakistan is not as favorable to teaching and learning of the language as it ought to be. The main reason is lack of trained teachers and effective and precise objectives of English curriculum. The majority of teachers teaching English language at schools depend upon outmoded instructional modus operandi. This paper serves as a measure to identify the current gaps in teaching of English at secondary school. It mainly compares the performance of students in four English skills (reading, writing, speaking, and listening) taught by traditional and skill-based English teaching methods. The findings reveal that there is no concept of skills-based language teaching among secondary school students and the subsequent testing of the expected skills across all secondary schools in Pakistan. This results in the lack of professional requirement for natural use of English amongst secondary school students.
\end{abstract}

Key Terms: Skill-based language teaching; English as a second language; traditional language teaching styles; Students' skills 


\section{Background of the Study}

Currently in Pakistani secondary schools, the assessment system prevailing in the majority of the secondary schools is not continuous summative, but still only summative in nature. This trend leads to the students relying on efforts to score well in the written assessments only disregarding the development of other English Language skills essential for the professional scenario. In order to measure eventual achievement, development or aptitude in language skills, skill-based teaching and formal tests should be conducted. In terms of each of the four basic language skills, namely speaking, reading, listening and writing each of the above mentioned qualities can be evaluated. For example, after using skill-based techniques to teach, analysis of the students' grasp of the language at the phonological stage, an assessment of achievement in understanding the spoken language can be administered. Such a test could be of the students' understanding regarding second language speech. Related tests can be considered to evaluate the other skills of English language as well. The gap is obvious because nearly all assessments in Pakistan are subjective and this is the main reason they only test the reading and writing skills of the students. These subjective tests do not assess the secondary school students' performance of the language rather limit them by only measuring the learners' knowledge of it.

On the other hand, to compete globally, the secondary schools across Pakistan are expected to provide more opportunities and experiences to the students to practice English language and to acquaint teachers with new techniques of teaching and assessing English language skills. These expectations can only be achieved by promoting more effective and skill-based methods of teaching and learning English language. However, such effective and skill-based methods of teaching and learning English language should be followed by realistic and

primarily skill-based assessment and evaluation techniques. The purpose of this research is to identify the current gaps in teaching quality of English teachers in secondary school and the impact it would have on the skills-based English language teaching and assessment at secondary school.

\section{Problem Statement}

Testing of English language skills in secondary schools in Pakistan does not assess the language skills that are required in the real professional work. Internationally accepted higher education institutions also emphasize 
and expect that English language skills of students in the crucial secondary years be developed and treated in a manner that adequately addresses the professional life requirement. This research explained efforts to assess the aptitude of the secondary English language learners for developing skills focusing on listening and reading comprehension, speaking and writing competency and grammatical structure. In addition, the study intended to shed light upon English language skill-based teaching strategies that focus on skill development pedagogy. In Pakistan, secondary education institutions do not focus on skill-based language teaching strategies and valid language tools are not utilized to teach and test English Language competency effectively (Malik, 2009).

Tests are expected to increase and uplift the needed skills for professional life and not just assess rote-learned facts and knowledge. The existing procedures of assessment in Pakistan are deficient in employing strategies so as to lessen the differences and problems between teaching and testing of the English language to higher secondary learners. Gronlund (2000) also substantiates that skill-based language test composed according to an instructional framework performs a very important part in undertaking the extent of the success or failure of language teaching program.

In Pakistan, the achievement of the secondary school's students in English language tests or exams depicts that the assessment procedures do not show the actual learning and skills of the students. Students' high scores in English language tests do not guarantee their proficiency in real life English language skills. This gap is more evident at private sector secondary schools across the country. Moreover, interestingly, the secondary school students in Pakistan extremely rely on the past examination patterns. For this purpose, the students collect the question papers from last five to seven years. Resultantly, an increasing interest is seen among the students to do selective study instead of mastering the required skills need for proficiency in English language.

\section{Research Hypothesis}

Following were the hypothesis of the study:

1. There is no difference in the scores of listening comprehension of students taught by traditional and skill-based English teaching methods. 
2. There is no difference in the scores of reading comprehension of students taught by traditional and skill-based English teaching methods.

3. There is no difference in the scores of writing of students taught by traditional and skill-based English teaching methods.

4. There is no difference in the scores of speaking of students taught by traditional and skill-based English teaching methods.

\section{Theoretical Framework}

This framework discusses the interpretive paradigm of the study. It is based upon cognitive and metacognitive learning and how these learning theories assist in developing the skill- based teaching strategies required to build up the capabilities of secondary schools' English Language learners. It also introduces the four skills required to improve English language. 


\section{Conceptual Framework of English Language Skill Development}

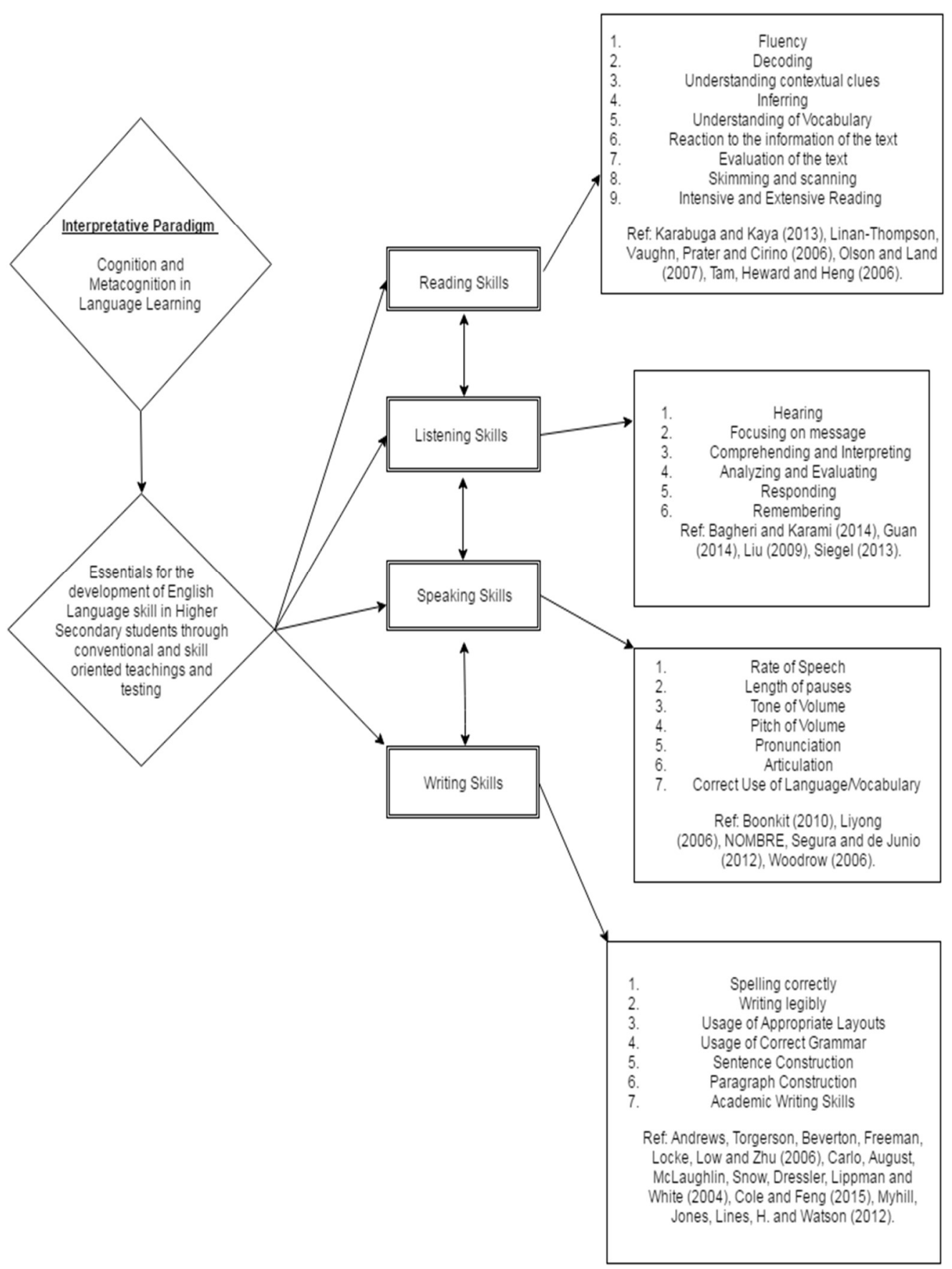




\section{Cognition and Metacognition in Language Learning}

In educational settings, applications of learning strategies related to cognitive psychology focus on understanding the impacts of strategy training for diverse types of works and students. Results from these researches usually signify that strategy training is valuable in enhancing the performance of English language learners on an extensive variety of reading and problemsolving tasks (Brown, Bransford, Ferrara, and Campione, 1983). Significant conclusions from these researches show that English language learning strategies include an executive, or metacognitive, function inclusive of cognitive processing.

Flavell (1979) says that language-based cognition is the process of knowing and perception through thinking and experiencing. Human cognition is mindful and unaware, tangible or intangible, as well as instinctive, like knowledge of a language and theoretical background like a model of a language. Vygotsky hypothesized that learners build up the capability for selfregulation during communication with more well-informed others (Vygotsky, 1978).

Pintrich (2002) states that learners who are aware about the various types of methodologies for learning language are more liable to utilize them. Efficient secondary English language students have various learning strategies suitable to personal goals and level of learning (Skehan, 1991). Research conducted upon learning of language have given significance to cognitive and meta cognitive learning strategies like the formation of hypothesis or language practice which is cognitive and planning and evaluating one's own learning which is meta cognitive (Oxford and Cohen, 1992).

Dunning, Johnson, Ehrlinger, and Kruger (2003) in their study "Why People Fail to Recognize Their Own Incompetence" discovered that generally people are ignorant of their lack of ability, lack awareness about deficits in their academic and communal skills. They recognized this design across many areas like test-taking, writing grammatically and thinking logically. Kaplan (2001) advocates that skill-based language teaching and assessing procedures need should be considered very crucial for contemporary secondary education. According to him, skill-based English language curriculum provides the experiential foundation to the students to learn all language skills and also prepares students for real professional world. 


\section{Listening Comprehension Skills}

An able listener is able to identify and understand what is being said. This comprises understanding the speakers, pronunciations, grammar, vocabulary and grasping the meaning all at the same time. It is a receptive skill which helps all the secondary students to acquire language subconsciously. Listening comprehension is an active process which requires practice and attention. Developing listening comprehension skills helps to understand and respond more effectively for secondary students. This leads to enhanced productivity, avoids conflicts, an improvement in relations and negotiation skills and also helps one to stand out and be appreciated improving selfconfidence. Listening comprehension is extremely vital for English proficiency because output is absent without input resulting in the absence of conversation without listening.

\section{Speaking Skills}

Speaking is conveying information verbally and exists in the expression of thought, feelings and ideas. Speaking ability is considered as the means of knowing a language by learners. It is the ability to converse fluently with others and is a mandatory as language skill. Experts in ELT are of the opinion that speaking can help students learn English, especially if they require the language to ask and answer questions. An individual who can speak English can produce speech and patterns both together and apart, use correct words and structures in order to express the intended meanings, logically sequence thoughts and ideas and adjust speech in accordance to the audience. Most educationists are of the opinion that due to the correct speaking skills, the learning of reading and writing skills has become easier. A good speaker generates words that are clear and informative to the listeners. In order to develop this skill, students need to practice intensively. Boonkit (2010) says that various factors relate to the skill of effective speaking.

\section{Reading Comprehension Skills}

Reading implies the understanding of meaning from written material. It is also famous for various advantages which include cultivating an active mind and reduction of stress. Reading helps discover new knowledge, develop imagination, improves creativity and is fundamental in developing a good selfimage. Reading enhances most features of the language in a secondary education student ranging from basic vocabulary to complex grammatical structures and also provides sound examples and formats for English writing. It improves the ability to construct sentences, paragraphs and texts, stimulates discussion, imaginative responses and fascinating classroom. 


\section{Writing Skills}

Writing is the inscription of characters on a medium, intending to create words or other constructs of language. By writing well, one earns respect as it clarifies thoughts, makes better learning and enhances the effective use of words in speech, both oral and written. Experts in applied language teaching are of the opinion that power to write good ideas in good English with clarity and confidence will always profit an individual. It is a vital part of language learning because when an individual writes, thoughts and information are blended to cultivate a meaning that is unique. This leads to the identification of writing on more complex issues by secondary students.

Schellekens \& Berry (2013) agrees with Wu (2012)) arguing that an assessment is fair if the test takers are allowed to show their capabilities in various ways, like different tests, approaches and formats of questions. Comprehensive and integrated testing of English language skills are usually the integral components in many standardized language testing programs. It cannot be denied that English has become an important language globally. It has been established that proficiency in English language can be improved by using conventional and skill-based English language teaching and assessment techniques.

The need of English language in Pakistan is discussed in the context of secondary school English language programs and research related to its practices. In Pakistani context, literacy in English is measured as a must, parallel to ICT skills for taking part in the existing style of globalization and becoming a component of the inclusive community. For example, Rahman (1999), in his study of student mindsets towards English in diverse types of schools in Pakistan established that the wish for learning English transpired amongst students from all school kinds inclusive of religious schools that symbolize the most traditional aspect of Pakistan's society. Likewise, Mansoor, Zafar, Hussain, Sikandar, Azam and Tatari (2005) in their study of language planning in Pakistan gave further proof of a vast requirement for learning English amid Pakistani secondary students. The current aptitude level in English of secondary students does not go with this style requirement for secondary English language in Pakistan.

\section{METHODOLOGY}

The research questions of this study posed the problem as to what extent the secondary English language students perform well if taught and tested using the teaching strategies that are majorly skill-based. This study 
adequately depended on the experimental design as it was framed for this format of research. The study endeavored to control the effect of many confounding variables, as it was necessary for the researcher to employ the experimental research design. This design is also effective in eliminating the effects of external and intervening variables largely. The experimental design in this experimental research was the predictor variable, being the strategic skill-based teaching which affected the performance of the treatment group. This performance is also known as the criterion variable.

Random sampling procedure with true experimental design was used in this study. Two groups of secondary English language students with initial homogeneity were employed to minimize bias and ensure randomization. A true experimental design in an educational setting focused upon the research participants who were selected randomly in order to study the impact of the treatment. Chance occurrence was what could have caused some difference in the two groups, control and experimental. Sampling error and sampling bias were controlled to a great extent. The true experimental design defined the true characteristics of the cause and effect relationship when the treatment group was given the treatment under the decided conditions and therefore was integral to this research. This design also ensured higher level of internal validity reducing internal threats to validity. The true experimental method of research measured what it was intended to measure. In educational research, when this design is employed, it provides and augments a strong comprehension of the impacts of the treatment upon the group, which has been experimented upon.

\section{Procedure}

Using standardized test, which follows the formats of TOEFL and IELTS, the competency of participating secondary English language students was tested. In order to make sure randomization and non-biased impacts upon the control and experimental groups of participants, pre-experiment testing was conducted employing a test of homogenous control variables. The predecided treatment was administered to the experimental group for a period of four months as defined by authorities in educational research.

After the experimental group underwent the treatment, the results were compared with the control groups' performance. SPSS V 21 was used for ensuring accuracy and the results assisted to test the hypothesis. This procedure helped the investigator to compare the performance of students taught by skillbased language teaching strategy with the traditional method of teaching English. All higher secondary English language students were the target 
population of the study. The sample was drawn from chartered and recognized secondary schools in Karachi comprising male and female students.

\section{Research Instrument}

The self-developed research instrument comprised the skill-based test with various items focusing various aspects designed by the experts in the field of linguistic testing. The instrument was administered on the experimental group whereas the control group was taught conventionally.

\section{Pilot Study}

The pilot study was conducted with $n=28$ secondary students enrolled in the regular English language courses offered at various private secondary schools across the city of Karachi. The main reason of pilot study was to find out the reliability and validity of the instrument.

\section{Method of Data Collection}

After randomly selecting respondents, their consent was taken. The both groups were requested to share their opinions after treatment. This technique was disguised strategy in which the researchers did not disclose to respondents that the control group was also asked the same questions the same time to ensure that internal validity threats do not interfere with the results and its generalization. The questionnaires were filled by the respondents and returned. The incomplete and late submitted questionnaires were not considered for data analysis. The researchers ensured that the minimum rate of return and rate of response were 95\%. Levene's test for equality of variance and t-test for equality of means was employed to compare the performance of students in four basic English language skills taught in traditional and skillbased teaching methods.

Results and Findings

The findings indicated that in terms of listening comprehension there is no difference in the scores of students taught by traditional and skill-focused English teaching methods. 
Table 1: Listening Comprehension Score in Secondary English Language

Independent Samples Test

\begin{tabular}{|c|c|c|c|c|c|c|c|c|c|}
\hline & \multicolumn{2}{|c|}{$\begin{array}{l}\text { Levene's Test for } \\
\text { Equality of Variances }\end{array}$} & \multicolumn{7}{|c|}{ t-test for Equality of Means } \\
\hline & \multirow[b]{2}{*}{$\mathrm{F}$} & \multirow[b]{2}{*}{ Sig. } & \multirow[b]{2}{*}{$t$} & \multirow[b]{2}{*}{ df } & \multirow{2}{*}{ Sig. (2-tailed) } & \multirow{2}{*}{$\begin{array}{l}\text { Mean } \\
\text { Difference }\end{array}$} & \multirow{2}{*}{$\begin{array}{l}\text { Std. Error } \\
\text { Difference }\end{array}$} & \multicolumn{2}{|c|}{$\begin{array}{c}95 \% \text { Confidence } \\
\text { Interval of the } \\
\text { Difference }\end{array}$} \\
\hline & & & & & & & & Lower & Upper \\
\hline $\begin{array}{ll}\text { Listening } & \text { Equal variance } \\
\text { Comprehension Scc assumed }\end{array}$ & 8.808 & .003 & -4.190 & 225 & .000 & -.98881 & .23600 & -1.45387 & -.52376 \\
\hline $\begin{array}{l}\text { Equal variance } \\
\text { not assumed }\end{array}$ & & & -4.229 & 212.880 & .000 & -.98881 & .23383 & -1.44973 & -.52789 \\
\hline
\end{tabular}

Levene's test for equality of variance and t-test for equality of means in Table 1 suggest that the test is significant. The $F$ test value reads 8.808 which is significant and so is the t-test value which reads -4.190 . The two-tailed independent sample t-test is highly significant with a mean difference between the two groups which reads -0.98881 . The test significance is also evident from the fact that the upper and lower confidence interval values at $95 \%$ significance level is a non-zero value which rejects the probability of equal means. PThe findings also indicated that in terms of speaking there is no difference in the scores of students taught by traditional and skill-focused English teaching methods.

Table 2: Speaking Test Score in Secondary English Language

\begin{tabular}{|c|c|c|c|c|c|c|c|c|c|}
\hline \multicolumn{10}{|c|}{ Independent Samples Test } \\
\hline & $\begin{array}{l}\text { Levene' } \\
\text { Equality o }\end{array}$ & $\begin{array}{l}\text { est for } \\
\text { ariances }\end{array}$ & \multicolumn{7}{|c|}{ t-test for Equality of Means } \\
\hline & \multirow{2}{*}{1} & \multirow[b]{2}{*}{ Sig. } & \multirow[b]{2}{*}{$t$} & \multirow[b]{2}{*}{ df } & \multirow[b]{2}{*}{ Sig. (2-tailed) } & \multirow{2}{*}{$\begin{array}{c}\text { Mean } \\
\text { Difference }\end{array}$} & \multirow{2}{*}{$\begin{array}{l}\text { Std. Error } \\
\text { Difference }\end{array}$} & \multicolumn{2}{|c|}{$\begin{array}{c}95 \% \text { Confidence } \\
\text { Interval of the } \\
\text { Difference }\end{array}$} \\
\hline & & & & & & & & Lower & Upper \\
\hline $\begin{array}{c}\text { Speaking Scol Equal variance } \\
\text { assumed }\end{array}$ & 3.211 & .074 & -2.357 & 225 & .019 & -.56900 & .24142 & -1.04473 & -.09327 \\
\hline $\begin{array}{l}\text { Equal variance } \\
\text { not assumed }\end{array}$ & & & -2.369 & 222.732 & .019 & -.56900 & .24021 & -1.04237 & -.09562 \\
\hline
\end{tabular}

Levene's test for equality of variance and t-test for equality of means in Table 2 suggest that the test is significant. The $\mathrm{F}$ test value reads 3.211 which is significant and so is the t-test value which reads -2.357 . The two-tailed independent sample t-test is significant with a mean difference between the two groups which reads -0.56900 . The test significance is also evident from the fact that the upper and lower confidence interval values at $95 \%$ significance level is a non-zero value which rejects the probability of equal means. 
The findings also indicated that in terms of reading comprehension there is no difference in the scores of students taught by traditional and skill-focused English teaching methods.

Table 3: Reading Comprehension Test Score in Secondary English Language

\begin{tabular}{|c|c|c|c|c|c|c|c|c|c|}
\hline \multicolumn{10}{|c|}{ Independent Samples Test } \\
\hline & \multicolumn{2}{|c|}{$\begin{array}{l}\text { Levene's Test for } \\
\text { quality of Variances }\end{array}$} & \multicolumn{7}{|c|}{ t-test for Equality of Means } \\
\hline & \multirow[b]{2}{*}{$\mathrm{F}$} & \multirow[b]{2}{*}{ Sig. } & \multirow[b]{2}{*}{$t$} & \multirow[b]{2}{*}{ df } & \multirow[b]{2}{*}{ Sig. (2-tailed } & \multirow{2}{*}{$\begin{array}{c}\text { Mean } \\
\text { Difference }\end{array}$} & \multirow{2}{*}{$\begin{array}{l}\text { Std. Error } \\
\text { Difference }\end{array}$} & \multicolumn{2}{|c|}{$\begin{array}{l}95 \% \text { Confidence } \\
\text { Interval of the } \\
\text { Difference }\end{array}$} \\
\hline & & & & & & & & Lower & Upper \\
\hline $\begin{array}{ll}\text { Reading } & \text { Equal varianc } \\
\text { Comprehension Sci assumed }\end{array}$ & 1.988 & .160 & -2.701 & 225 & .007 & -.57685 & .21361 & -.99777 & -.15592 \\
\hline $\begin{array}{l}\text { Equal varianc } \\
\text { not assumed }\end{array}$ & & & -2.711 & 224.254 & .007 & -.57685 & .21282 & -.99622 & -.15747 \\
\hline
\end{tabular}

Levene's test for equality of variance and t-test for equality of means in Table 3 suggest that the test is significant. The $F$ test value reads 1.988 which is significant and so is the t-test value which reads -2.701 . The two-tailed independent sample t-test is significant with a mean difference between the two groups which reads -0.57685 . The test significance is also evident from the fact that the upper and lower confidence interval values at $95 \%$ significance level is a non-zero value which rejects the probability of equal means.

The findings also indicated that in terms of writing there is no difference in the scores of students taught by traditional and skill-focused English teaching methods.

Table 4: Writing Test Score of Secondary English Language Students

\begin{tabular}{|c|c|c|c|c|c|c|c|c|c|}
\hline \multicolumn{10}{|c|}{ Independent Samples Test } \\
\hline & \multicolumn{2}{|c|}{$\begin{array}{c}\text { Levene's Test for } \\
\text { Equality of Variances }\end{array}$} & \multicolumn{7}{|c|}{ t-test for Equality of Means } \\
\hline & \multirow[b]{2}{*}{$\mathrm{F}$} & \multirow[b]{2}{*}{ Sig. } & \multirow[b]{2}{*}{$\mathrm{t}$} & \multirow[b]{2}{*}{ df } & \multirow[b]{2}{*}{ Sig. (2-tailed) } & \multirow{2}{*}{$\begin{array}{c}\text { Mean } \\
\text { Difference }\end{array}$} & \multirow{2}{*}{$\begin{array}{l}\text { Std. Error } \\
\text { Difference }\end{array}$} & \multicolumn{2}{|c|}{$\begin{array}{l}95 \% \text { Confidence } \\
\text { Interval of the } \\
\text { Difference }\end{array}$} \\
\hline & & & & & & & & Lower & Upper \\
\hline $\begin{array}{c}\text { Writing Scor' Equal variance } \\
\text { assumed }\end{array}$ & 1.318 & .252 & -2.922 & 225 & .004 & -.66193 & .22654 & -1.10834 & -.21552 \\
\hline $\begin{array}{l}\text { Equal variance } \\
\text { not assumed }\end{array}$ & & & -2.935 & 223.507 & .004 & -.66193 & .22554 & -1.10638 & -.21747 \\
\hline
\end{tabular}

Levene's test for equality of variance and t-test for equality of means in Table 4 suggest that the test is significant. The $F$ test value reads 1.318 which is significant and so is the t-test value which reads -2.922 . The two-tailed 
independent sample t-test is significant with a mean difference between the two groups which reads -0.66193 . The test significance is also evident from the fact that the upper and lower confidence interval values at $95 \%$ significance level is a non-zero value which rejects the probability of equal means.

\section{Conclusion}

When secondary English students learn through skill-based language teaching strategy, they enjoy learning English language more as there are various opportunities to express emotions. Similarly, skill-based language teaching strategy is more durable as a teaching method as in conventional settings, teachers seem to dominate the process of teaching and learning entirely through their planned lectures. The other glaring findings drawn through this research was that in skill-based secondary English language class, students also get to listen to various types of native and near-native accents of English and express feelings at the end of every single listening comprehension exercise.

On the other hand, in a skill-based lesson, secondary students work in pairs and groups to discuss various events when the teacher arranges an activity for oral communication. This opportunity is denied otherwise in conventional lecture-based and translation-based teaching practices. The study also concludes that secondary English students enjoy different forms of reading exercises in groups and pairs. They also enjoy vocabulary building activities as they get excited to find and share their answers. This opportunity is denied in conventional lecture based teaching methodology. The other significant conclusion drawn from the study is that in a conventional lecture-based class, students enjoy reading lessons in performing reading tasks which is not a part of traditional teaching approach. There is more writing possible in this form of teaching English language with corrective feedback mechanism. 


\section{References}

Boonkit, K. (2010). Enhancing the development of speaking skills for nonnative speakers of English. Procedia-Social and Behavioral Sciences, 2(2), 1305-1309.

Brown, A. L., Bransford, J. D., Ferrara, R. A., \& Campione, J. C. (1983). Handbook of child psychology. P. Mussen, JH Flavell \& EM Markman (Eds.), 3, 77-166.

Brown, G. L \& Yule, G. N. (1999) Teaching the Spoken Language. Cambridge University Press 1999. Cambridge.

Dunning, David, Johnson, Kerri, Ehrlinger, Joyce, and Kruger, Justin. (2003) Why people fail to recognize their own incompetence. Current Directions in Psychological Science, 12(3). 83-87.

Flavell, J. H. (1979). Metacognition and cognitive monitoring: A new area of cognitive-developmental inquiry. American Psychologist, 34, 906911.

Gronlund (2000). How to write and use language instructional objectives. (6th

Ed.). Prentice Hall. NJ.

Kaplan, R. B. (2001). English - the accidental language of science? In U. Ammon (Ed.).

The dominance of English as a language of science: Effects on other language and language communities. New York: Mouton de Gruyter.

Malik, F (2009). The Teaching of English in Pakistan. Lahore: Vanguard.

Oxford, R. L., \& Cohen, A. D. (1992). Language Learning Strategies: Crucial Issues of Concept and Classification. Applied Language Learning, 3, $1-35$.

Pintrich, Paul R. (2002). The Role of metacognitive knowledge in learning, teaching, and assessing. Theory into Practice, 41(4). 219-225

Rahman, T. (1999). Language, Education and Culture. Karachi: Oxford University Press.

Rao, Z. (2007). Training in brainstorming and developing writing skills. ELT journal, 61(2), 100-106.

Schellekens, P., \& Berry, V. (2013) Setting standards for professional and academic contexts.

Siegel, J. (2013). Second language learners' perceptions of listening strategy instruction. Innovation in Language Learning and Teaching, 7(1), 1-18.

Skehan, P. (1991). Individual differences in second language learning. Studies in second language acquisition, 13(02), 275-298. 
Tanner, Kimberly D. (2012). Promoting student metacognition. CBE-Life Sciences Education, 11, 113-120.

Vygotsky, L. (1978) Interaction between Learning and Development. In Gauvian \& Cole (Eds) Readings on the Development of Children. Scientific American Books Pp 34-40.

$\mathrm{Wu}$, Jessica RW. "GEPT and English language teaching and testing in Taiwan." Language Assessment Quarterly 9, no. 1 (2012): 11-25. 